\title{
Implementasi Fungsi Legislasi Dewan Perwakilan Rakyat Daerah pada Pembentukan Peraturan Daerah
}

\author{
Arifuddin N \\ Fakultas Ilmu Pemerintahan, STISIP Petta Baringeng, Soppeng \\ ${ }^{\Omega}$ Surel Koresponden: arifuddin2571@gmail.com
}

\begin{abstract}
:
This study aims to analyze the implementation of DPRD members 'initiative rights and the factors that hinder the exercise of DPRD members' initiative rights in the formation of Regional Regulations. This type of research is normative juridical research, the source of this research data is secondary data consisting of primary legal materials, secondary legal materials, and tertiary legal materials. The collected legal materials are processed and compiled systematically and provide detailed and in-depth explanations to reveal problems regarding the legislative function of DPRD members with the intention of seeking consistency between applicable legal norms.

The results showed that the implementation of DPRD members' initiative rights in the formation of regional regulations was still not optimal even though it had referred to PP No. 12 of 2018 concerning Guidelines for the Preparation of DPRD Standing Orders, because many DPRD members have never used the right of initiative in preparing academic texts and the Draft of Regional Regulation. The inhibiting factors for the implementation of DPRD members' initiative rights in the formation of regional regulations consist of human resources, the effectiveness and efficiency of the use of the budget, the role of the Expert Team, as well as low community participation being an inhibiting factor. The suggestion that the authors propose is that DPRD members in carrying out the legislative function should not only wait for the proposed Regional Regulation coming from the Regional Government, but actively use their initiative right in forming Local Regulations as regulated in the legislation, as well as addressing the factors existing obstacles in order to optimize the implementation of the initiative rights of DPRD members.
\end{abstract}

Keywords: right of initiative; legislative function; local regulation;

\begin{abstract}
Abstrak:
Penelitian ini bertujuan untuk menganalisis pelaksanaan hak inisiatif Anggota $D P R D$ dan faktor-faktor yang menghambat pelaksanaan hak inisiatif anggota DPRD pada pembentukan Peraturan Daerah. Tipe penelitian yang digunakan adalah penelitian yuridis normatif, sumber data penelitian ini adalah data sekunder yang terdiri dari bahan hukum primer, bahan hukum sekunder, dan bahan hukum tertier. Bahan hukum yang berhasil dikumpulkan diolah dan disusun secara sistematis dan memberikan penjelasan secara rinci dan mendalam untuk mengungkap permasalahan mengenai fungsi legislasi anggota DPRD dengan maksud mencari konsistensi antara norma hukum yang berlaku.Hasil penelitian menunjukan bahwa Pelaksanaan hak inisiatif anggota DPRD dalam pembentukan peraturan daerah masih kurang optimal sekalipun telah mengacu pada PP No. 12 Tahun 2018 tentang Pedoman Penyusunan Peraturan Tata Tertib DPRD, karena banyak anggota DPRD yang tidak pernah menggunakan hak inisiatifnya dalam penyusunan naskah akademik dan Rancangan Peraturan Daerah. Faktor penghambat pelaksanaan hak inisiatif anggota DPRD dalam pembentukan peraturan daerah terdiri dari Faktor
\end{abstract}


sumber daya manusia, efektifitas dan efisiensi penggunaan anggaran, peranan Tim Ahli, serta partisipasi masyarakat yang rendah menjadi faktor penghambat. Adapun saran yang penulis ajukan adalah, hendaknya anggota DPRD dalam melaksanakan fungsi legislasi tidak sekedar menunggu usulan Rancangan Perda yang berasal dari Pemerintah Daerah, tetapi secara aktif mempergunakan hak inisiatifnya dalam membentuk Peraturan Daerah sebagaimana yang diatur dalam peraturan perundang-undangan, serta mengatasi faktor-faktor penghambat yang ada agar dapat mengoptimalkan pelaksanaan hak inisiatif anggota DPRD.

Kata Kunci: hak inisiatif; fungsi legislasi; peraturan daerah;

Submission: 23-03-2020

Accepted: 09-05-2020

Doi: https://doi.org/10.56087/aijih.v23i1.36

\section{PENDAHULUAN}

Produk Peraturan Daerah merupakan kewenangan Pemerintah Daerah (Pemda) dan Dewan Perwakilan Rakyat Daerah (DPRD). Hal itu utamanya dilaksanakan sejak era Otonomi Daerah diamanahkan melalui Undang-undang Nomor 5 Tahun 1974 Tentang Pokok-pokok Pemerintahan di Daerah, Undang-undang Nomor 22 Tahun 1999 Tentang Pemerintahan daerah, kemudian diganti menjadi Undang-undang 32 Tahun 2004, dan selanjutnya berlaku sampai saat ini yakni Undang-undang Nomor 23 Tahuin 2014.

Aktivitas pembentukan Perda sebagaimana peraturan perundang-undangan yang lainnya, harus dimaknai sebagai suatu proses yang kompherensif. Dalam Pasal 1 Ayat (1) Undang-undang No. 12 Tahun 2011 tentang Pembentukan Peraturan Perundangundangan, menyatakan bahwa: "Pembentukan Peraturan Perundang-undangan adalah pembuatan Peraturan Perundang-undangan yang mencakup tahapan perencanaan, penyusunan, pembahasan, pengesahan atau penetapan, dan pengundangan". Hal ini menegaskan bahwa pembentukan Perda tidak sekedar meliputi proses pembahasan dan pengesahan sebagaimana yang biasanya secara awam dipahami dan dipraktekkan tetapi yang dimaksud dengan pembentukan Perda adalah keseluruhan proses.

Sebagai lembaga representasi kepentingan rakyat demi menghasilkan penyelenggaraan pemerintahan demokratis, dan pembangunan yang berkualitas di tingkat lokal, maka fungsi legislasi merupakan salah satu dari tiga fungsi DPRD yang vital dan strategis. Sehingga terkait dengan pembentukan peraturan daerah maka 
anggota DPRD diberikan hak inisiatif dalam mengusulkan rancangan peraturan daerah (Rancangan Perda). Dengan hak inisiatif ini memungkinkan DPRD dapat menjadi lembaga yang aspiratif dalam memperjuangkan kepentingan masyarakat konstituennya secara kreatif dan pro-aktif dalam bentuk kebijakan-kebijakan legislasi di tingkat daerah. Bukan sebaliknya hanya bersifat pasif dan cenderung menunggu sehingga usulan peraturan daerah (Perda) hanya didominasi oleh eksekutif daerah.

Fenomena lebih dominannya kepala daerah (pemerintah daerah) dalam menjalankan tugas pemerintahan, pembangunan, dan pelayanan publik disebabkan oleh kualitas anggota DPRD senantiasa kalah dengan pemerintah daerah. DPRD kurang memiliki tanggung jawab baik dari sisi responsibilitas (responsibility), akuntabilitas (accountability), maupun responsivitas (responsiveness) dalam menjalankan tugas dan fungsi kedewanan. DPRD kurang atau boleh dikatakan tidak berdaya dalam mengenali, menyampaikan, dan memperjuangkan apa yang menjadi masalah, kebutuhan, dan aspirasi dari rakyat yang diwakilinya. ${ }^{1}$

Kurangnya peranan DPRD dalam menggunakan hak inisiatifnya, dilihat dari kualitas anggota DPRD, sangat sedikit anggota DPRD yang memiliki pengetahuan dan pengalaman yang menunjang kemampuan guna menyusun suatu Rancangan Perda dan ditambah lagi kurangnya pelatihan-pelatihan yang diperoleh untuk meningkatkan kualitas anggota. ${ }^{2}$ Kemudian dilihat dari sarana dan prasarana yang ada seperti minimnya perpustakaan dan minimnya buku-buku serta bahan-bahan lainnya belum sepenuhnya menunjang kelancaran tugas kedewanan.

Rendahnya jumlah Rancangan Perda inisiatif, disebabkan oleh dua faktor. Pertama, faktor keberadaan Panleg (Panitia Legislatif) dan supporting system termasuk anggaran dan tenaga perancang Perda. Ada perbedaan antara DPRD yang tidak

\footnotetext{
${ }^{1}$ Joko Widodo, Good Governance, Telaah dari Dimensi Akuntabilitas dan Kontrol Birokrasi Pada Era Desentralisasi dan Otonomi Daerah, dalam Faisal Abdullah, Pemberdayaan DPRD Menuju Clean and Good Governance, Jurnal Ilmu Hukum Amannagappa, Vol. 12, No. 3, September 2004, hal. 237-238

2 Yarni, M. (2010). Fungsi legislasi DPRD dalam kerangka otonomi: studi kasus DPRD kota Jambi dan DPRD kabupaten Muaro Jambi. Jurnal Ilmiah Hukum LEGALITY. hal.11
} 
dilengkapi dengan Panleg dan DPRD yang memiliki Panleg sebagai salah satu alat kelengkapannya. ${ }^{3}$

Terkait dengan kurang produktifnya Dewan Perwakilan Rakyat menjalankan fungsi legislasi, hal tersebut diungkapkan oleh Nur Sholikin bahwa "Memasuki satu tahun periode jabatannya, Dewan Perwakilan Rakyat gagal membuktikan hasil kerja legislasinya. Bukan persoalan jumlah, namun kinerja selama ini tidak memberikan bukti nyata bidang legislasi, lebih lanjut dikatakannya bahwa penilaian kinerja legislasi tidak hanya dilihat dari sisi kuantitas produk yang dibuat, namun segi kualitasnya juga menjadi faktor penting dalam menilai produk legislasi. ${ }^{4}$

Sehubungan dengan hal tersebut, menurut Aristo Efandy A. Barlian bahwa "berdasarkan data dari Kementerian Dalam Negeri telah tercatat lebih dari 3.000 Perda yang dibatalkan dan masih terdapat ribuan Perda yang direkomendasikan untuk dievaluasi dan/atau dibatalkan. Meskipun Perda yang dibatalkan pada umumnya Perda tentang pajak dan retribusi daerah, sebelum berlakunya Undangundang No. 32 Tahun 2004 sampai Undang-undang No. 23 Tahun 2014 tentang Pemerintahan Daerah sudah 8000 Perda tentang Pajak dan Retribusi Daerah yang dibuat dan lebih dari 3.000 Perda tersebut terindikasi bermasalah. ${ }^{5}$

Hingga Maret 2016, Presiden Jokowi memerintahkan Menteri Dalam Negeri Tjahjo Kumolo membatalkan 3.143 Peraturan Daerah (Perda) dan Peraturan Kepala Daerah (Perkada) yang dianggap bermasalah di seluruh Indonesia. Sehubungan dengan itu, maka Pada Juni 2016 Kemneterian dalam Negeri (Kemendagri) secara resmi mengumumkan pembatalan 3.143 Perda dan Perkada yang dianggap bermasalah tersebut. Adapun Perda yang dihapus diantaranya terkait investasi dan pendidikan. ${ }^{6}$ Meskipun pada waktu yang berbeda, dalam sidang Pleno Mahkamah Konstitusi yang

\footnotetext{
${ }^{3}$ R. Siti Zuhro dan Eko Prasojo (Editor) 2010, Kisruh Peraturan Daerah :Mengurai Masalah dan Solusinya, Penerbit Ombak dan The Habibie Center, Yogyakarta. hal. 66

${ }^{4}$ Ratna Solihah, Siti Witianti, 2016, Pelaksanaan Fungsi Legislasi Dewan Perwakilan Rakyat Pasca Pemilu 2014 : Permasalahan dan Usaha Mengatasinya, Jurnal Ilmu Pemerintahan “COSMOGOV” Vol. 2 No. 2, Oktober 2016. Program Studi Ilmu Fisip, Universitas Padjadjaran, Bandung. pp. 292.

${ }^{5}$ Aristo Efandy A. Barlian , 2016, Konsistensi Pembentukan Peraturan Daerah Berdasarkan Hierarki Perundang-undangan Dalam Perpektif Politik Hukum, Jurnal Ilmu Hukum Fiat Justisia, Volume 10 Number, 4, October-December 2016. Fak. Hukum Universitas Lampung, Bandar Lampung. hal. 615

${ }^{6}$ Kementerian Dalam Negeri (Kemendagri) Republik Indonesia, Daftar Keputusan Menteri Dalam Negeri tentang Pembatalan Peraturan Daerah dan KDH 2004-2014 yang bermasalah, www.kemendagri.go.id./news/2016/06/21/daftar pembatalan-3143-perda-masih-perlupenyempurnaan. (Diakses Sabtu, 23 Februari 2019)
} 
terbuka untuk umum pada tanggal 5 April 2017, melalui Putusan No. 137/PUUXII/2015 menyatakan, Pasal 251 Undang-undang No. 251 Tentang Pemerintahan Daerah terkait dengan kewenangan pembatalan peraturan daerah kabupaten / kota tidak lagi bisa dibatalkan oleh Menteri Dalam Negeri atau Gubernur. ${ }^{7}$

Lahirnya Putusan Mahkamah Konstitusi yang menyatakan Pasal 251 Ayat (2), Ayat (3), Ayat (4) dan Ayat (8) Undang-undang 23 tahun 2014 Tentang Pemerintahan Daerah bertentangan dengan UUD Negara RI Tahun 1945, dan tidak mempunyai Hukum mengikat, maka kewenangan uji materi terhadap Peraturan Daerah Kabupaten / Kota dan Peraturan Bupati / Walikota tidak lagi berada di bawah Pemerintah Pusat. ${ }^{8}$ Meskipun pada kenyataannya Keputusan Menteri dalam Negeri tersebut tidak sepenuhnya dijalankan, mis; Pemerintah Kabupaten Aceh Timur di Provinsi Aceh terdapat 6 (enam) Qanun yang dibatalkan oleh Menteri Dalam Negeri, namun baru 5 (lima) Qanun yang sudah direvisi dan saat ini masih ada 1 (satu) Qanun yang dilaksanakan sampai sekarang yaitu Qanun Kabupaten Aceh Timur No. 2 Tahun 2013 Tentang Retribusi Perizinan Tertentu. Adapun alasan masih dilaksanakannya ketentuan dalam Qanun tersebut adalah karena dalam Surat Keputusan Menteri Dalam Negeri tidak disebutkan ketentuan-ketentuan mana saja yang harus dibatalkan tetapi hanya disebutkan Qanun secara keseluruhan. ${ }^{9}$

Berbagai uraian di atas menunjukan kurangnya kemampuan legislasi DPRD termasuk dalam penggunaan hak inisiatif pembentukan Perda yang di dalam prosedur pelaksanaan hak inisiatif itu meliputi pengajuan Rancangan Perda, pembahasan Rancangan Perda, dan pengambilan keputusan untuk memutuskan usul rancangan peraturan daerah berupa persetujuan, persetujuan dengan pengubahan, atau penolakan.

Peraturan daerah (Perda) merupakan instrumen dalam pelaksanaan otonomi daerah untuk menentukan arah dan kebijakan pembangunan daerah serta fasilitas

\footnotetext{
${ }^{7}$ Eka NAM Sihombing, 2017, Perkembangan Pembatalan Peraturan Daerah dan Peraturan Kepala Daerah, Jurnal Yudisial Vol. 10, 10 Agustus 2017, Fakultas Hukum Universitas Sumatera Utara, pp. 218

${ }^{8}$ Efendi, 2017, Hak Uji Materi Pemerintah Terhadap Peraturan Daerah (kajian Terhdap Kewenangan Pemerintah Pusat Pasca Putusan Mahkamah Konstitusi No. 137/PUU-XII/2015), Jurnal Ilmu Syari'ah dan Hukum, Volume 51, No. 1 Juni 2017, pp. 145.

${ }_{9}$ Rahmat Qadri Nasrun, Husni Djalil, Efendi, 2019, Kedudukan Peraturan Daerah Yang Dibatalklan Oleh Keputuisan Menteri Dalam Negeri Setelah Putusan Mahkamah Konstitusi No. 137/PUU-XIII/2015, Syiaih Kuala Law Jurnal, Aceh ; Vol. 3, No. 1 April 2019. pp. 99-100
} 
pendukungnya. Namun, dalam perkembangan praktik otonomi daerah, persoalan demi persoalan muncul berkenaan dengan penetapan dan pelaksanaan Perda ini, sampai kemudian Pemerintah (Pusat) kewalahan untuk melaksanakan pengawasan sampai pembatalannya. ${ }^{10}$ Perda adalah produk daerah yang unik, karena dihasilkan dari sebuah proses yang didominasi kepentingan politik lokal. Sejak otonomi daerah bergulir, muncul ribuan Perda pajak dan retribusi daerah yang memberatkan investor. ${ }^{11}$ Perda ini dianggap menimbulkan masalah ekonomi biaya tinggi yang berdampak bagi pertumbuhan ekonomi, baik lokal maupun nasional. Sehingga banyak pemerintah daerah yang memanfaatkan peluang meningkatkan PAD melalui Perda. ${ }^{12}$

Pada implementasinya, kurang optimalnya penyelenggaraan pemerintahan daerah, termasuk pembentukan Perda yang pro-rakyat bukan sepenuhnya merupakan tanggung jawab Pemerintah Daerah, akan tetapi merupakan tanggung jawab bersama (joint responsibility) antara DPRD dan Pemerintah Daerah. Hal ini merupakan konsekwensi logis dari reposisi kedudukan dan kewenangan DPRD di era reformasi yang sebelumnya hanya merupakan "tukang stempel” kebijakan menjadi mitra sejajar Pemerintah Daerah dalam penyelenggaraan pemerintahan daerah. Bahkan dalam Pasal 75 jo Pasal 76 Undang-undang No. 12 Tahun 2011 tentang Pembentukan Peraturan Perundang-undangan serta Pasal 7 PP No. 12 Tahun 2018 tentang Pedoman Penyusunan Peraturan Tata Tertib Dewan Perwakilan Rakyat Daerah, ditegaskan bahwa pembahasan Rancangan Perda inisiatif anggota DPRD lebih diprioritaskan jika penyampaiannya bersamaan dengan Rancangan Perda yang berasal dari pemerintah daerah dalam suatu masa sidang, maka uraian ini menyentuh permasalahan sebagai berikut, yaitu; Bagaimana pelaksanaan hak inisiatif anggota DPRD dalam pembentukan Peraturan Daerah? dan Apa faktor penghambat pelaksanaan hak inisiatif anggota DPRD dalam pembentukan Peraturan Daerah?

${ }^{10}$ Bunga, M. (2017). Pembentukan Peraturan Daerah Dalam Penyelenggaraan Otonomi Daerah. AlIshlah: Jurnal Ilmiah Hukum, 19(2), 12-25. hal, 20

11 Lontoh, R. L. (2019). Problems of Border Regions in Ensuring Legal Certainty Invest in Indonesia. Substantive Justice International Journal of Law, 2(2), 118-136. hal, 120

12 Muhammad Suharjono, 2014, DIH Jurnal Ilmu Hukum, Volume 10 No. 19 Pebruari 2014. pp. 22. 


\section{METODE}

Berdasar pada karakteristik masalah yang diajukan dalam penelitian ini yang berfokus pada pelaksanaan hak inisiatif anggota DPRD dalam pembentukan peraturan daerah, maka penelitian ini termasuk dalam tipe penelitian yuridis normatif, dimana fokus penelitiannya adalah pada bahan-bahan pustaka. Jadi menggunakan tipe penelitian hukum normatif (normative legal research) yang menurut Soerjono Soekanto dan Sri Mamudji disebut juga dengan istilah penelitian kepustakaan dengan cara meneliti bahan-bahan pustaka atau data sekunder saja. ${ }^{13}$

Merujuk pada tipe penelitian yang digunakan dalam penelitian ini yaitu penelitian hukum normatif, maka digunakan pendekatan perundang-undangan (statute approach) dengan cara menelaah semua undang-undang dan regulasi yang berkaitan dengan Undang-undang No. 12 Tahun 2011 Tentang Pembentukan Peraturan Perundang-undangan, Undang-Undang No. 23 Tahun 2014 Tentang Pemerintahan Daerah, Undang-undang No. 17 Tahun 2014 Tentang MD3, Serta Peraturan Pemerintah No. 12 Tahun 2018 Tentang Pedoman Penyusunan Tata Tertib DPRD Provinsi, Kabupaten, dan Kota.

Sumber data dalam penelitian ini adalah data sekunder yang terdiri dari bahan hukum primer, bahan hukum sekunder, dan bahan hukum tertier. Bahan hukum yang berhasil dikumpulkan peneliti diolah dan disusun secara sistematis sehingga menghasilkan dan memberikan penjelasan secara rinci dan mendalam untuk mengungkap permasalahan dengan maksud mencari konsistensi antara norma hukum yang berlaku dengan pelaksanaannya, khususnya mengenai fungsi legislasi anggota DPRD pada pembentukan peraturan daerah.

13 Menurut Soerjono Soekanto dan Sri Mamudji bahwa, data sekunder meliputi bahan hukum primer, bahan hukum sekunder dan bahan hukum tertier. Bahan hukum primer adalah bahan hukum yang mengikat yaitu perundang-undangan (UUD 1945 dan seterusnya), hukum adat, yurisprudensi dan traktat. Bahan hukum sekunder adalah bahan hukum yang memberikan penjelasan mengenai bahan hukum primer seperti rancangan undang-undang, hasil penelitian, hasil karya dari kalangan hukum dan seterusnya, bahan hukum tertier adalah bahan hukum yang memberikan petunjuk maupun penjelasan terhadap bahan hukum primer dan bahan hukum sekunder, misalnya ; kamus, ensiklopedi, indek komulatif dan sebagainya. 


\section{PEMBAHASAN}

Menurut teori, fungsi badan legislatif daerah yang paling pokok ialah:14

1. menentukan policy (kebijakan) dan membuat peraturan daerah. untuk merealisasi fungsi-fungsi ini, DPRD mempunyai wewenang, hak inisiatif (prakarsa), hak amandemen.

2. Menentukan Anggaran Pendapatan Belanja Daerah (APBD), yang tercakup dalam hak budget (anggaran).

3. Mengontrol badan eksekutif (Pemerintah Daerah) melalui hak-hak DPRD.

Ketentuan Pasal 96 Ayat (1) Undang-undang No. 23 Tahun 2014 disebutkan bahwa: "DPRD memiliki fungsi legislasi, anggaran, dan pengawasan". Hal yang sama mengenai fungsi DPRD Provinsi dan kabupaten/kota diatur dalam Pasal 149 Ayat (1) yang menyebutkan bahwa; "DPRD memiliki fungsi legislasi, anggaran, dan pengawasan", demikian pula halnya dalam Pasal 2 Ayat (1) PP No. 12 Tahun 2018. Selanjutnya dalam PP No. 12 Tahun 2018 ditegaskan bahwa fungsi legislasi diwujudkan dalam membentuk peraturan daerah, fungsi anggaran diwujudkan dalam membahas dan menyetujui RAPBD bersama kepala daerah, fungsi pengawasan diwujudkan dalam mengawasi pelaksanaan peraturan daerah dan APBD.

Melalui fungsi legislasi ini sesungguhnya menempatkan DPRD pada posisi yang sangat strategis dan terhormat, karena DPRD ikut serta sebagai mitra sejajar pemerintah daerah menentukan keberlangsungan dan masa depan daerah. Hal ini juga harus dimaknai sebagai amanah untuk memperjuangkan dan meningkatkan kesejahteraan rakyat. ${ }^{15}$

Mekanisme kinerja legislasi ini dapat dicermati dalam dua bentuk. ${ }^{16}$ Pertama, mekanisme konvensional. Mekanisme ini cenderung mirip dengan apa yang dilakukan sebelum pelaksanaan otonomi, yaitu bergerak pasif. DPRD menerima usulan Rancangan Perda dari eksekutif, kemudian membahasnya hingga disetujui

\footnotetext{
${ }^{14}$ Soetandjo Wignosubroto, dkk, Pasang Surut Otonomi Daerah: Sketsa Perjalanan 100 Tahun, Institute for Local Government, 2005, hal. 410

${ }^{15}$ Sadu Wasistiono dan Yonatan Wiyoso, 2009, Meningkatkan Kinerja DewanPerwakilan Rakyat Daerah (DPRD), Fakusmedia, Bandung. Hal.35

${ }^{16}$ Wawan Sobari, dkk, Inovasi Sebagai Referensi: Tiga Tahun Otonomi Daerah dan Otonomi Award, Nailil Printika, Yogyakarta, 2004, hal.105-106
} 
menjadi sebuah Perda baru. Fenomena yang berbeda dari sebelumnya, DPRD sekarang bisa juga tidak sekedar pasif menunggu usulan eksekutif, tetapi mendesak eksekutif untuk mengajiukan suatu Rancangan Perda, terutama yang menyangkut hal-hal krusial dan menjadi sumber masalah di daerah. ${ }^{17}$

Kedua, mekanisme review (pengkajian). Dalam praktiknya, sekarang DPRD sudah mempunyai inisiatif untuk mau mengkaji ulang Perda lama yang berjalan dan Perda baru yang dianggap mengalami resistensi dari masyarakat. Tujuannya yaitu selain melihat efektifitas berjalannya Perda, juga untuk mencari kemungkinan melakukan revisi terhadap Perda tersebut.

Ketiga, penggunaan hak inisiatif. DPRD membentuk panitia-panitia kerja untuk melakukan kajian. Hasil kajian panitia kerja berupa draft Rancangan Perda dibahas secara internal di DPRD, yang kemudian diajukan dalam pembahasan bersama eksekutif, hingga disahkan Perda tersebut.

Fungsi legislasi, pengawasan, dan anggaran yang dijustifikasi dalam undang-undang ini merupakan modal yuridis bagi DPRD untuk memerankan fungsinya sebagai lembaga perwakilan rakyat di tingkat lokal, sehingga dapat terbangun dinamika check and balances dalam penyelenggaraan pemerintahan daerah.

Diluar ketiga fungsi DPRD seperti tersebut di atas, sebenarnya masih ada fungsi lain yaitu fungsi representasi yang arti dan maknanya sangat mendasar. ${ }^{18}$ Hal ini berkaitan dengan mandat yang diberikan pemilih kepada wakilnya di DPRD. Fungsi representasi seharusnya berkaitan dengan fungsi-fungsi lainnya, karena secara hipotesis setiap anggota DPRD adalah merepresentasikan rakyat yang diwakilinya. Anggota DPRD harus bertindak dan berperilaku sebagai representant (wakil) untuk setiap tindak dan tanduknya dalam seluruh kegiatan dalam menjalankan tugas sebagai salah satu anggota DPRD. Karena kedudukan tersebut ia memiliki posisi terhormat yang juga harus diimbangi dengan perbuatan dan hasil kerja yang produktif dan berguna bagi rakyat yang diwakilinya. Anggota DPRD adalah "duta",

\footnotetext{
${ }^{17}$ Moonti, R. M. (2017). Hakikat Otonomi Daerah Dalam Sistem Ketatanegaraan Di Indonesia. AlIshlah: Jurnal Ilmiah Hukum, 19(2), 26-37.

18 Soetandjo Wignosubroto, dkk, Pasang Surut Otonomi Daerah: Sketsa Perjalanan 100 Tahun, Institute for Local Government, Jakarta, 2005, hal. 421
} 
“pembawa suara”, "penyambung lidah”, pelindung dari rakyat yang mempercayakan suara padanya lewat suatu pemilihan umum.

\section{A. Hak Inisiatif Anggota Dewan Perwakilan Rakyat Daerah dalam Pembentukan Peraturan Daerah}

Fungsi pertama lembaga perwakilan rakyat adalah fungsi legislasi atau pengaturan, dalam bentuk konkretnya, fungsi pengaturan (regelende functie) ini terwujud dalam fungsi pembentukan undang-undang (wetgevende functie atau law making function). ${ }^{19}$ Selain itu, fungsi legislatif juga menyangkut empat bentuk kegiatan yaitu: ${ }^{20}$

1) prakarsa pembentukan undang-undang (legislative inisiation);

2) pembahasan rancangan undang-undang (law making process);

3) persetujuan atas pengesahan rancangan undang-undang (law enactment approval);

4) Pemberian persetujuan pengikatan atau ratifikasi atas perjanjian atau persetujuan internasional dan dokumen-dokumen hukum yang mengikat lainnya (Binding decision making on international agreement and treaties or other legal binding documents).

Hak inisiatif anggota DPRD ini secara tegas diformulasikan dalam Pasal 107 (hak anggota DPRD Provinsi) dan Pasal 159 (hak anggota DPRD kabupaten/kota) Undangundang No. 23 Tahun 2014 serta Pasal 78 PP No. 12 Tahun 2018. Selain itu, hak inisiatif Anggota DPRD dalam pembentukan Perda ini merupakan hak yang lebih diutamakan (prioritas) dibanding hak Gubernur atau Bupati/Walikota dalam hal yang sama sebagaimana yang ditegaskan dalam Pasal 62 Undang-undang No. 12 Tahun 2011.21

Konkretisasi dari fungsi legislasi DPRD (salah satunya) adalah hak inisiatif dalam mengajukan Rancangan Perda yang kemudian bersama-sama kepala daerah (the

\footnotetext{
${ }^{19}$ Jimly Asshiddiqie, Pengantar Ilmu Hukum Tata Negara, Cetakan II, PT Raja Grafindo Persada, Jakarta, 2010, hal. 299

20 Ibid, hlm. 300

${ }^{21}$ Lihat Pasal 63 PP No. 12 Tahun 2018 “ Ketentuan mengenai penyusunan Peraturan Daerah Provinsi sebagaimana dimaksud dalam Pasal 56 sampai dengan Pasal 62 berlaku secara mutatis mutandis terhadap penyusunan Peraturan Daerah Kabupaten/kota".
} 
head of local government) melakukan persetujuan bersama (joint authority) untuk menjadi Perda. Secara prosedural, Rancangan Perda dapat disampaikan oleh anggota, komisi, gabungan komisi atau oleh Badan Legislasi (Baleg) DPRD, yang kesemuanya diatur oleh Peraturan Tata Tertib DPRD. DPRD dalam hal ini sesungguhnya harus mempunyai target dalam setiap tahunnya, dan bahkan lebih dari itu dapat membuat target program untuk lima tahunan, yang kemudian diadaptasi dengan Prolegda (Program Legislasi Daerah). ${ }^{22}$

Agar pelaksanaan hak inisiatif dapat memberikan hasil (output) berupa Rancangan Perda yang berkualitas maka pelaksanaan hak inisiatif ini perlu masukan-masukan (input) dalam proses pelaksanaan tersebut. Hasil yang dimaksud ini baik dari sisi kuantitas maupun kualitas Rancangan Perda, dimana kuantitas menyangkut jumlah Rancangan Perda yang dihasilkan, sedangkan kualitas menyangkut Rancangan Perda tersebut memenuhi kriteria yang ditetapkan dalam proses pembentukan Perda yang baik termasuk memenuhi aspirasi dan keinginan masyarakat luas sehingga apabila Rancangan Perda tersebut ditetapkan menjadi Perda maka akan efektif untuk diberlakukan.

Dengan menggunakan pendekatan input dan output dalam peningkatan kualitas peraturan perundang-undangan, diungkapkan bahwa terdapat lima konteks yang perlu dicermati agar proses pembentukan peraturan perundang-undangan dapat menghasilkan peraturan perundang-undangan yang berkualitas, yaitu: ${ }^{23}$
a. Input dan Output Tahap Pra Rancangan
b. Input dan Output Tahap Perancangan
c. Input dan Output Dari Masyarakat
d. Input dan output Tahap Pembahasan di DPR/DPRD
e. Input dan output Tahap Penegakan Hukum.

Mengacu pada lingkup atau cakupan dalam prosedur hak inisiatif anggota DPRD, maka agar para perancang suatu peraturan perundang-undangan (Perda) dapat menghasilkan kualitas produk hukum yang berkualitas baik dapat dicapai manakala pembentukannya memenuhi tiga hal pokok, yaitu landasan pemikiran (dimensi

\footnotetext{
22 Suprin Na'a, Ke Arah Parlemen Lokal yang Berdaya, nusantaraku.org, diakses Sabtu 23 Februari 2019

${ }^{23}$ HAS Natabaya, 2007, Peningkatan Kualitas Peraturan Perundang-undangan (Suatu Pendekatan Input dan Output), Jurnal Legislasi Indonesia, Vol. 4 No. 2, Juni 2007, hal. 9-16
} 
filosofis, sosiologis, yuridis, dan politis), perancangan yang mengacu pada model perancangan modern, dan terwujudnya sinergitas yang riil antara kultur hukum dan perancangan peraturan perundang-undangan. Ketiganya dapat diistilahkan sebagai the three pillars of quality of legal product. ${ }^{24}$

Mekanisme pembentukan Perda berdasarkan Pasal 32 sampai dengan Pasal 41 Undang-undang No. 12 Tahun 2011 tentang Pembentukan Peraturan PerundangUndangan Juncto Pasal 9 sampai dengan Pasal 22 Peraturan Pemerintah No. 12 Tahun 2018 tentang Pedoman Penyusunan Peraturan Dewan Perwakilan Rakyat Daerah Tentang Tata Tertib Dewan Perwakilan Rakyat Daerah, ${ }^{25}$ dapat diuraikan sebagai berikut:

\section{a. Persiapan Pembentukan Perda Inisiatif DPRD}

Rancangan Perda dapat berasal dari DPRD atau gubernur, atau bupati/walikota, masing-masing sebagai kepala pemerintah daerah Provinsi, Kabupaten, atau Kota. ${ }^{26}$ Rancangan peraturan daerah yang berasal dari DPRD atau kepala daerah disertai penjelasan atau keterangan dan/atau naskah akademik. ${ }^{27}$

Naskah akademik yang dipersyaratkan dalam rancangan peraturan daerah adalah sesuai dengan Pasal 1 Ayat (11) adalah naskah hasil penelitian atau pengkajian hukum dan hasil penelitian lainnya terhadap masalah tertentu yang dapat dipertanggung jawabkan secara ilmiah mengenai pengaturan masalah tersebut dalam suatu rancangan undang-undang, rancangan peraturan daerah provinsi, atau rancangan peraturan daerah Kabupaten/Kota sebagai solusi permasalahan dan kebutuhan masyarakat. ${ }^{28}$

${ }^{24}$ Achmad Ruslan, Pembentukan Peraturan Perundang-Undangan dan Kualitas Produk Hukumnya (Kajian Pereda tentang Pajak dan Retribusi di Sulawesi Selatan), Jurnal Ilmu HUkum Amannagappa, Vo. 13, Nomor 2 Juni 2005, hal. 117.

25 PP No. 12 Tahun 2018. ini lahir karena diundangkannya Undang-undang Nomor 2 Tahun 2018 tentang Majelis Permusyawaratan Rakyat, Dewan Perwakilan Rakyat, Dewan Perwakilan Daerah, dan Dewan Perwakilan Rakyat Daerah.

${ }^{26}$ Lihat Pasal 34 Undang-Undang No. 23 Tahun 2014, Bandingkan dengan Pasal 5 Ayat (1) PP No. 12 Tahun 2018

27 Pasal 56 Ayat (2) Undang-undang No. 12 Tahun 2011. Bandingkan dengan Pasal 5 Ayat (2) PP No. 12 Tahun 2018.

28 Suharyo, 2015, Pembentukan Peraturan Daerah, dan Penerapan Sanksi Pidana Serta Problematikanya, Jurnal Rechtsvinding Media Pembinaan Hukum Nasional, Volume 4 No. 03 - Desember 2015. pp. 437. 
Rancangan Perda sebagaimana dimaksud diajukan berdasarkan program pembentuikan Perda atau di luar program pembentukan Perda sesuai dengan ketentuan perundang-undangan. ${ }^{29}$ Program Legislasi Daerah adalah instrumen perencanaan program pembentukan Peraturan Daerah Provinsi atau Peraturan Daerah Kabupaten/Kota yang disusun secara terencana, terpadu, dan sistematis, ${ }^{30}$ kecuali dalam keadaan tertentu, DPRD atau kepala daerah dapat mengajukan rancangan peraturan daerah di luar program legislasi daerah, ${ }^{31}$ yang dimaksud dengan "keadaan tertentu" adalah untuk mengatasi keadsaan luar biasa, keadaan konflik, atau bencana alam; akibat kerja sama dengan pihak lain, atau keadaan tertentu lainnya yang memastikan adanya urgensi atas suatu Rancangan Peraturan Daerah Provinsi yang dapat disetujui bersama oleh alat kelengkapan DPRD Provinsi yang khusus menangani bidang legislasi dan biro hukum. ${ }^{32}$

Rancangan Perda yang berasal dari hak inisiatif DPRD dapat disampaikan oleh anggota, komisi, gabungan komisi, atau alat kelengkapan DPRD Provinsi yang khusus menangani bidang legislasi. ${ }^{33}$ Ketentuan lebih lanjut mengenai tata cara mempersiapkan Rancangan Perda ini diatur dalam Peraturan Tata Tertib DPRD. 34

Rancangan Perda tersebut disampaikan oleh pimpinan DPRD kepada Badan Pembentukan Peraturan Daerah (Bapemperda) untuk dilakukan pengkajian dalam rangka pengharmonisasian, pembulatan, dan pemantapan konsepsi rancangan Perda. ${ }^{35}$ Selanjutnya, Rancangan Perda yang telah dikaji oleh Bapemperda tersebut disampaikan oleh Pimpinan DPRD kepada semua

29 Pasal 5 Ayat (3) PP No. 12 Tahun 2018. Hal ini juga diisyaratkan dalam Pasal 32 Undang-Undang No. 12 Tahun 2011, bahwa: "Perencanaan penyusunan Perda Provinsi Dilakukan dalam suatu Prolegda Provinsi” jo Pasal 40, bahwa ; "Ketentuan mengenai perencanaan penyusunan Perda Provinsi ini berlaku secara mutatis mutandis terhadap perencanaan penyusunan Perda Kabupaten/Kota".

30 Pasal 1 Ayat (10) Undang-undang No. 12 Tahun 2011

31 Ibid. Pasal 38 Ayat (2)

32 Penjelasan Pasal 81 Ayat (4) PP No. 12 Tahun 2018

33 Lihat Pasal 60 Ayat (1) Undang-undang No. 12 Tahun 2011. Bandingkan dengan Pasal 6 Ayat (1) PP No. 12 Tahun 2018 yang menyatakan bahwa " Rancangan Perda yang berasal dari DPRD dapat diajukan oleh Anggota DPRD, komisi, gabungan komisi, atau Bapemperda yang dikoordinasikan oleh Bapemperda".

34 Ibid. Pasal 60 Ayat (2)

35 Lihat Pasal 6 Ayat (3) PP No. 12 Tahun 2018. Bandingkan dengan Pasal 61 Ayat (1) Undangundang No. 12 Tahun 2011 yang menyatakan bahwa " Rancangan Peraturan Daerah Provinsi yang telah disiapkan oleh DPRD Provinsi disampaikan dengan surat pimpinan DPRD Provinsi kepada Gubernur" 
anggota DPRD laping lambat 7 (tujuh) hari sebelum rapat paripurna DPRD. ${ }^{36}$ Kemudian pimpinan DPRD menyampaikan hasil pengkajian Bapemperda atas Rancangan Perda tersebut kepada Rapat Paripurna DPRD. ${ }^{37}$

Dalam rapat paripurna sebagaimana yang dimaksud diatas:

a. Pengusul memberikan penjelasan;

b. Fraksi dan anggota DPRD lainnya memberikan pandangan; dan

c. Pengusul memberikan jawaban atas pandangan fraksi dan anggota DPRD lainnya. ${ }^{38}$

Rapat paripurna DPRD memutuskan usul Rancangan Perda sebagaimana yang dimaksud pada nomor 2 (dua) diatas, berupa: ${ }^{39}$

a. Persetujuan;

b. Persetujuan dengan pengubahan; atau

c. Penolakan.

Apabila ternyata pada Sidang Paripurna diputuskan bahwa Rancangan Peraturan Daerah yang diajukan tersebut dinyatakan "persetujuan dengan pengubahan", maka DPRD menugaskan komisi, gabungan komisi, atau Bapemperda untuk menyempurnakan rancangan Perda. ${ }^{40}$

Rancangan Perda yang telah disiapkan oleh DPRD disampaikan oleh Pimpinan DPRD kepada gubernur atau bupati/walikota. ${ }^{41}$ Apabila dalam suatu masa sidang, gubernur atau bupati/walikota dan DPRD menyampaikan Rancangan perda mengenai materi yang sama, yang dibahas adalah Rancangan Perda yang disampaikan oleh DPRD, sedangkan Rancangan Perda yang disampaikan oleh gubernur atau bupati/walikota digunakan sebagai bahan persandingan. ${ }^{42}$

36 Pasal 6 Ayat (4) PP No. 12 Tahun 2018

37 Ibid. Pasal 6 Ayat (5)

38 Ibid. Pasal 6 Ayat (6)

39 Ibid. Pasal 6 Ayat (7)

40 Ibid. Pasal 6 Ayat (8)

41 Ibid Pasal 6 Ayat (9) Bandingkan dengan Undang-undang No. 12 Tahun 2011. Pasal 78 Ayat (1) menyatakan, bahwa: "Rancangan Peraturan Daerah yang telah disetujui bersama oleh DPRD Provinsi dan Gubernur disampaikan oleh pimpinan DPRD kepada Gubernur untuk ditetapkan menjadi Peraturan Daerah Provinsi".

42 Lihat Pasal 62 Undang-undang No. 12 Tahun 2011 jo Pasal 8 PP No. 12 Tahun 2011 
Sebagaimana Rancangan Undang-undang (RUU), Rancangan Perda juga disebarluaskan, misalnya, melalui media informasi, mis ; TVRI, RRI, Internet, ataupun media cetak, seperti surat kabar, majalah, dan edaran di daerah yang bersangkutan sehingga khalayak ramai mengetahui adanya Rancangan Perda yang dibahas di DPRD yang bersangkutan. Dengan demikian, masyarakat dapat memberikan masukan secara lisan atau tertulis atas materi Rancangan Perda yang sedang dibahas tersebut. ${ }^{43}$

\section{b. Pembahasan Rancangan Perda}

Pembahasan Rancangan Perda di DPRD dilakukan oleh DPRD bersama gubernur atau bupati/walikota. ${ }^{44}$ Pembahasan bersama tersebut dilakukan melalui tingkat-tingkat pembicaraan, yakni dilakukan dalam rapat komisi/panitia/badan/alat kelengkapan DPRD Provinsi yang khusus menangani bidang legislasi dan rapat paripurna. Ketentuan lebih lanjut mengenai tata cara pembahasan Rancangan Perda diatas diatur dengan Peraturan Tata Tertib DPRD. 45

Tingkat-tingkat pembicaraan itu dilakukan melalui 2 (dua) tingkat pembicaraan, yaitu pembicaraan tingkat I dan pembicaraan tingkat II. Pembicaraan tingkat I meliputi: 46

a. Dalam hal Rancangan Perda berasal dari Kepala Daerah :

1. Penjelasan Kepala Daerah dalam rapat paripurna mengenai rancangan Perda.

2. Pandangan umum fraksi terhadap rancangan Perda; dan

3. Tanggapan dan/atau jawaban Kepala Daerah terhadap pemandangan umum Fraksi

b. Dalam hal Rancangan Perda berasal dari DPRD dilakukan dengan kegiatan, sbb:

\footnotetext{
43 Lihat Pasal 88-94 Undang-undang No. 12 Tahun 2011

44 Ibid. Pasal 75 Ayat (1)

45 Ibid. Pasal 75 Ayat (3), dan (4)

46 Pasal 9 Ayat (3) PP No. 12 Tahun 2018
} 
1) Penjelasan pimpinan komisi, pimpinan gabungan komisi, pimpinan Badan Pembentukan Peraturan Daerah (Bapemperda), atau pimpinan panitia khusus dalam rapat paripurna mengenai Rancangan Perda;

2) Pendapat kepala daerah terhadap Rancangan Perda;

3) Tanggapan dan/atau jawaban fraksi terhadap pendapat Kepala Daerah.

c. Pembahasan dalam rapat komisi, gabungan komisi, atau panitia khusus yang dilakukan bersama dengan Kepala Daerah atau pejabat yang ditunjuk untuk mewakili.

d. Penyampaian pendapat akhir fraksi dilakukan pada akhir pembahasan antara DPRD dan Kepala Daerah atau pejabat yang ditunjuk untuk mewakili.

Pembicaraan tingkat II meliputi: ${ }^{47}$

a. Pengambilan keputusan dalam rapat paripurna yang didahului dengan:

1) Penyampaian laporan yang berisi proses pembahasan, pendapat fraksi, dan hasil pembicaraan tingkat I oleh pimpinan komisi, pimpinan gabungan komisi, atau pimpinan panitia khusus;

2) Permintaan persetujuan secara lisan pimpinan rapat kepada anggota dalam rapat paripurna; dan

3) Pendapat akhir Kepala Daerah.

b. Dalam hal persetujuan sebagaimana dimaksud pada huruf a angka 2 tidak dapat dicapai secara musyawarah untuk mufakat, keputusan diambil berdasarkan suara terbanyak.

c. Dalam hal Rancangan Perda tidak mendapat persetujuan bersama antara DPRD dan Kepala Daerah, Rancangan Perda tersebut tidak dapat diajukan lagi dalam persidangan DPRD masa sidang itu.

Selanjutnya, mengenai Rancangan Peraturan Daerah dapat ditarik kembali sebelum dibahas bersama oleh DPRD dan gubernur atau bupati/walikota. Penarikan kembali Rancangan Perda sebagaimana yang dimaksud di atas, oleh DPRD dilakukan dengan keputusan pimpinan DPRD dengan disertai alasan penarikan. Penarikan kembali

\footnotetext{
47 Ibid. Pasal 9 Ayat (4)
} 
Rancangan Perda sebagaimana dimaksud diatas oleh kepala daerah, disampaikan dengan surat kepala daerah disertai alasan penarikan. ${ }^{48}$

Rancangan Perda yang sedang dibahas hanya dapat ditarik kembali berdasarkan persetujuan bersama DPRD dan gubernur atau bupati/walikota. Penarikan kembali Rancangan Perda hanya dapat dilakukan dalam rapat paripurna yang dihadiri oleh Kepala Daerah, dan Rancangan Perda yang ditarik kembali tidak dapat diajukan lagi pada masa sidang yang sama. ${ }^{49}$

\section{c. Penetapan Rancangan Perda}

Rancangan Perda yang telah disetujui bersama oleh DPRD dan gubernur atau bupati/walikota disampaikan oleh pimpinan DPRD kepada Gubernur atau Bupati/Walikota untuk ditetapkan menjadi Perda. Penyampaian Rancangan Perda yang dimaksud di atas dilakukan dalam jangka waktu paling lambat 7 (tujuh) hari terhitung sejak tanggal persetujuan bersama. ${ }^{50}$

Rancangan Perda yang telah disetujui bersama dan telah disampaikan oleh pimpinan DPRD ditetapkan oleh gubernur atau bupati/walikota dengan membubuhkan tanda tangan dalam jangka waktu paling lambat 30 (tiga puluh) hari sejak Rancangan Perda tersebut disetujui bersama oleh DPRD dan Gubernur atau Bupati/Walikota. 51

Apabila Rancangan Perda dimaksud tidak ditandatangani oleh Gubernur atau Bupati/Walikota dalam waktu paling lambat 30 (tiga puluh) hari sejak Rancangan Perda tersebut disetujui bersama, Rancangan Perda tersebut sah menjadi Perda dan wajib diundangkan dalam Lembaran Daerah. ${ }^{52}$

\section{d. Pengundangan dan Penyebarluasan}

Pengundangan dan penyebarluasan Perda berfungsi agar setiap orang dapat mengetahuinya. Pengundangan Perda sekaligus memiliki makna spesifik bahwa

\footnotetext{
48 Ibid. Pasal 10 Ayat (1), (2), dan (3)

49 Ibid. Pasal 10 Ayat (4), (5), dan (6)

50 Ibid. Pasal 11 Ayat (1) dan (2

51 Pasal 79 Ayat (1) Undang-undang No. 12 Tahun 2011

52 Ibid. Pasal 79 Ayat (2)
} 
Perda telah positif berlaku. Perda diundangkan dalam Lembaran Daerah, Tambahan Lembaran Daerah; atau Berita Daerah. ${ }^{53}$

Namun, tidak semua Rancangan Perda yang telah disetujui bersama dan ditandatangani oleh DPRD dan Gubernur atau Bupati / Walikota serta merta dapat diundangkan, karena Rancangan Perda yang berkaitan dengan Rencana pembangunan Jangka Panjang Daerah, Rencana pembangunan Jangka Menengah Daerah, APBD, perubahan APBD, pertanggungjawaban pelaksanaan APBD, pajak daerah, retribusi daerah, dan tata ruang daerah sebelum diundangkan dalam lembaran daerah harus dievaluasi oleh Pemerintah dan/atau gubernur sesuai dengan peraturan perundang-undangan. ${ }^{54}$

Terkait penyebarluasan pemerintah daerah wajib menyebarluaskan Perda yang telah diundangkan dalam Lembaran Daerah dan peraturan di bawahnya yang telah diundangkan dalam Berita Daerah. ${ }^{55}$ Adapun tujuan peyebarluasan Rancangan Perda dinyatakan dalam Pasal 92 Undang-undang No. 12 Tahun 2011 bahwa: Yang dimaksud dengan "menyebarluaskan” adalah agar khalayak ramai mengetahui Peraturan Perundang-undangan di daerah yang bersangkutan dan mengerti/memahami isi serta maksud-maksud yang terkandung di dalamnya agar memperoleh masukan dari masyarakat dan pemangku kepentingan lainnya. Penyebarluasan Peraturan Perundangundangan tersebut dilakukan, misalnya, melalui media elektronik seperti Televisi Republik Indonesia dan Radio Republik Indonesia, stasiun daerah, atau media cetak yang terbit di daerah yang bersangkutan".

\section{B. Faktor-Faktor Penghambat Pelaksanaan Hak Inisiatif Anggota DPRD dalam Pembentukan Peraturan Daerah}

Fenomena lebih dominannya kepala daerah (pemerintah daerah) dalam menjalankan tugas pemerintahan, pembangunan, dan pelayanan publik disebabkan oleh kualitas anggota DPRD senantiasa kalah dengan pemerintah daerah. ${ }^{56}$ DPRD kurang memiliki tanggung jawab baik dari sisi responsibilitas (responsibility),

\footnotetext{
53 Ibid. Pasal 81 Jo. Pasal 86 Ayat (1), (2), dan (3)

54 Pasal 12 PP No. 12 Tahun 2018

55 Pasal 81 Undang-undang No. 12 Tahun 2011

56 Joko Widodo, Loc.cit
} 
akuntabilitas (accountability), maupun responsivitas (responsiveness) dalam menjalankan tugas dan fungsi kedewanan. DPRD kurang atau boleh dikatakan tidak berdaya dalam mengenali, menyampaikan, dan memperjuangkan apa yang menjadi masalah, kebutuhan, dan aspirasi dari rakyat yang diwakilinya.

Kurangnya peranan DPRD dalam menggunakan hak inisiatifnya, dilihat dari kualitas anggota DPRD, sangat sedikit anggota DPRD yang memiliki pengetahuan dan pengalaman yang menunjang kemampuan guna menyusun suatu Rancangan Perda dan ditambah lagi kurangnya pelatihan-pelatihan yang diperoleh untuk meningkatkan kualitas anggota. Kemudian dilihat dari sarana dan prasarana yang ada seperti minimnya perpustakaan dan minimnya buku-buku serta bahan-bahan lainnya belum sepenuhnya menunjang kelancaran tugas kedewanan. ${ }^{57}$

Pandangan lain juga mengemukakan terkait rendahnya jumlah Rancangan Perda Inisiatif pada dua wilayah yang pernah mereka adakan penelitian, disebabkan oleh dua faktor, yaitu: ${ }^{58}$ Pertama, faktor keberadaan Panleg (Panitia Legislatif) dan supporting system termasuk anggaran dan tenaga perancang Perda. Ada perbedaan antara DPRD yang tidak dilengkapi dengan Panleg dan DPRD yang memiliki Panleg sebagai salah satu alat kelengkapannya. Selain itu, rendahnya hak inisiatif ini diantaranya disebabkan oleh kurangnya perhatian dari partai politik sendiri dalam urusan mengajukan suatu isu untuk dijadikan Perda. 59

Demikian pula halnya pendapat lain bahwa, seharusnya perlu diadakan perubahan dalam rangka penyusunan program pembentukan Peraturan Daerah, utamanya menyangkut anggaran.60 Sudah sepatutnya pemerintah daerah mengadakan perubahan penganggaran pembentukan Peraturan Daerah untuk memudahkan proses pembentukan Peraturan Daerah tidak mengalami hambatan di waktu-waktu yang akan datang, dan dapat menghasilkan Peraturan Daerah yang lebih berkualitas. Karena dengan penganggaran yang memadai, suatu Rancangan Peraturan Daerah dapat dialokasikan terlebih dahulu untuk pembuatan naskah akademik.

${ }^{57}$ Meri Yarni, Loc.cit

58 R. Siti Zuhro dan Eko Prasojo, Loc.cit

59 Ibid, hal. 66

60 Eka NAM Sihombing, 2016, Problematika Penyusunan Program Pembuatan Peraturan Daerah, Jurnal Legislasi Indonesia Vol. 13, No. 03 - September 2016. pp. 294. 
Selanjutnya, hal-hal yang dapat dilakukan dalam kaitannya untuk memperoleh Rancangan Peraturan Daerah yang memperjuangkan kepentingan rakyat adalah adanya partisipasi masyarakat. Pelaksanaan peran serta masyarakat dalam pembentukan Peraturan Daerah antara lain; ${ }^{61}$ dilakukannya rapat dengar pendapat umum atau rapat-rapat lainnya yang bertujuan menyerap aspirasi masyarakat, dilakukannya kunjungan oleh anggota DPRD untuk mendapat masukan dari masyarakat, ataupun diadakannya seminar-seminar atau kegiatan yang sejenis dalam rangka melakukan pengkajian atau menindak lanjuti berbagai penelitian untuk menyiapkan suatu Rancangan Peraturan Daerah.

Hal tersebut sejalan dengan apa yang diamanatkan dalam Pasal 96 Undang-undang No. 12 tahun 2011 yang menyatakan bahwa ; (1) Masyarakat berhak memberikan masukan secara lisan dan/atau tertulis dalam pembentukan peraturan perundangundangan, (2) Masukan secara lisan dan/atau tertulis sebagaimana dimaksud pada ayat (1) dapat dilakukan melalui a. Rapat dengar pendapat umum, b. kunjungan kerja, c. Sosialisasi, d. Seminar, lokakarya, dan/atau diskusi. (3) Masyarakat sebagaimana dimaksud pada ayat (1) adalah orang perseorangan atau kelompok orang yang mempunyai kepentingan atas substansi Rancangan peraturan perundang-undangan. (4) Untuk memudahkan masyarakat dalam memberikan masukan secara lisan dan/atau tertulis, maka rancangan tersebut harus dapat diakses dengan mudah oleh masyarakat. ${ }^{62}$ Olehnya. berbagai faktor yang menghambat implementasi hak inisiatif anggota DPRD dalam pembentukan Perda. Faktor-faktor tersebut antara lain:

1. Sumber Daya Manusia, yakni kemampuan masing-masing anggota DPRD dalam mengartikulasikan kebutuhan dan aspirasi masyarakat menjadi suatu produk kebijakan diantaranya peraturan daerah. Mengenai hal ini dibutuhkan tiga hal

\footnotetext{
61 Amir Muhiddin, 2013, Partisipasi Masyarakat Dalam Pembuatan Peraturan Daerah, Jurnal Ilmu Pemerintahan “OTORITAS” Vol. III No. 1 April 2013. pp. 8

62 Bandingkan dengan Pasal 188 Peraturan Presiden (PERPRES) No. 87 Tahun 2014 Tentang Peraturan Pelaksanaan Undang-undang No. 12 Tahun 2011 Tentang Pemebentukan Peraturan Perundang-undangan. Bahwa “ (1) Masyarakat berhak memberikan masukan secara lisan dan/atau tertulis dalam pembentukan peraturan perundang-undangan. (2) Ketentuan sebagaimana dimaksud pada ayat (1) dilaksanakan dalam rangka melaksanakan konsultasi publik. (3) Ketentuan mengenai tata cara pelaksanaan konsultasi publik diatur dengan Peraturan Menteri.
} 
yang paling mendasar yaitu integritas, kemampuan konseptual, dan keterampilan legislative drafting.

2. Anggaran, yakni anggaran yang dialokasikan khusus untuk pembentukan Peraturan Daerah.

3. Peranan Tim Ahli, yaitu tenaga professional dibidangnya yang diangkat untuk membantu DPRD dalam melaksanakan fungsi, tugas, dan wewenangnya di bidang legislasi.

4. Partisipasi masyarakat, peran serta atau keikutsertaan masyarakat untuk mengawasi, mengontrol, dan mempengaruhi kebijakan pemerintah mulai dari perencanaan sampai dengan evaluasi pelaksanaan kebijakan tersebut.

\section{KESIMPULAN DAN SARAN}

Pelaksanaan hak inisiatif anggota DPRD dalam pembentukan peraturan daerah telah mengacu pada PP No. 12 Tahun 2018 tentang Pedoman Penyusunan Peraturan Tata Tertib DPRD Provinsi, Kabupaten, dan Kota. Akan tetapi masih banyak anggota DPRD yang tidak pernah menggunakan hak inisiatifnya serta pelibatan masyarakat dalam penyusunan naskah akademik dan Rancangan Perda masih belum memadai. Berikutnya, faktor-faktor yang menghambat pelaksanaan hak inisiatif anggota DPRD dalam membentuk Peraturan daerah adalah: Sumber Daya Manusia. Anggaran,. Peranan Tim Ahli, dan Partisipasi masyarakat dalam proses pembentukan Perda termasuk Perda yang berasal dari inisiatif DPRD

Adapun sarannya adalah Anggota DPRD dalam melaksanakan fungsi legislasi tidak sekedar menunggu usulan Rancangan Perda yang berasal dari Pemerintah Daerah, tetapi secara aktif mempergunakan hak inisiatifnya dalam membentuk Peraturan Daerah sebagaimana yang diatur dalam peraturan perundang-undangan. Untuk mengatasi faktor-faktor yang menghambat pelaksanaan hak inisiatif anggota DPRD dalam membentuk Perda dengan cara: Mengadakan pelatihan yang terkait dengan peningkatan keterampilan legislative drafting bagi anggota DPRD dan memberdayakan peranan Tim Ahli dalam memberikan penguatan substansi pada naskah akademik dan Partisipasi masyarakat dalam proses pembentukan Perda termasuk Perda yang berasal dari inisiatif DPRD harus ditingkatkan dengan memperjelas pengaturan mengenai mekanisme partisipasi masyarakat dalam proses 
pembentukan Perda, serta perubahan mindset yang konvensional di tingkat aktoraktor CSO (Civil Society Organization) menjadi mindset yang responsif terhadap agenda pembentukan Perda.

\section{REFERENSI}

Achmad Ruslan, Peraturan Daerah dan HAM dalam Pelaksanaan Otonomi Daerah, Jurnal Ilmu Hukum Amanna Gappa, Volume 11, No. 4 Tahun 2003.

Pembentukan Peraturan Perundang-Undangan dan Kualitas Produk Hukumnya (Kajian Pereda tentang Pajak dan Retribusi di Sulawesi Selatan), Jurnal Ilmu Hukum Amannagappa, Vo. 13, Nomor 2 Juni 2005.

Amir Muhiddin, 2013, Partisipasi Masyarakat Dalam Pembuatan Peraturan Daerah, Jurnal Ilmu Pemerintahan “OTORITAS” Vol. III No. 1 April 2013. pp. 1-9

Aristo Efandy A. Barlian , 2016, Konsistensi Pembentukan Peraturan Daerah Berdasarkan Hierarki Perundang-undangan Dalam Perspektif Politik Hukum. Jurnal Ilmu Hukum Fiat Justisia, Volume 10 Number, 4, October-December 2016. Fak. Hukum Universitas Lampung, Bandar Lampung. pp 605-622.

Bunga, M. (2017). Pembentukan Peraturan Daerah Dalam Penyelenggaraan Otonomi Daerah. Al-Ishlah: Jurnal Ilmiah Hukum, 19(2), 12-25.

Eka NAM Sihombing, 2016, Problematika Penyusunan Program Pembentukan Peraturan Daerah, Jurnal Legislasi Indonesia Vol. 13, No.03 - September 2016. pp. 285-296. 2017, Perkembangan Kewenangan Pembatalan Peraturan Daerah dan Peraturan Kepala Daerah, Jurnal Yudisial Vol. 10, 10 Agustus 2017. Fakultas Hukum Universitas Muhammadiyah Sumatera Utara. pp. 217-234

Efendi, 2017, Hak Uji Materi Pemerintah Terhadap Peraturan Daerah (kajian Terhadap Kewenangan Pemerintah Pusat Pasca Putusan Mahkamah Konstitusi No. 137/PUU-XII/2015), Jurnal Ilmu Syari'ah dan Hukum, Volume 51, No. 1 Juni 2017.

Faisal Abdullah, 2004, Pemberdayaan DPRD Menuju Clean and Good Governance, Jurnal Ilmu Hukum Amannagappa, Vol. 12, No. 3, September 2004. 
Hans Kelsen, Teori Umum tentang Hukum dan Negara, Penerjemah Raisul Muttaqien, Cetakan IV, Nusa Media, Bandung, 2009.

H.A.S. Natabaya, 2007, Peningkatan Kualitas Peraturan Perundang-undangan (Suatu Pendekatan Input dan Output), Jurnal Legislasi Indonesia, Vol. 4 No. 2, Juni 2007.

Jimly Asshiddiqie, 2010, Pengantar Ilmu Hukum Tata Negara, Cetakan II, PT Raja Grafindo Persada, Jakarta, 2010.

Kementerian Dalam Negeri (Kemendagri) Republik Indonesia, Daftar Keputusan Menteri Dalam Negeri tentang Pembatalan Peraturan Daerah dan KDH 2004-2014, www.depdagri.go.id. Diakses Sabtu, 23 Februari 2019.

Muhammmad Reza Winata, Mery Christian Putri, Zaka Firma Aditya, 2018, Legal Historis Kewenangan Pengujian dan Pembatalan Peraturan Daerah Serta Implikasinya Terhadap Kemudahan Berusaha, Jurnal Rechtsvinding Media Pembinaan Hukum Nasional, Volume 7 Desember 2018. pp. 615-622

Muhammad Suharjono, 2014, DIH Jurnal Ilmu Hukum, Volume 10 No. 19 Pebruari 2014. pp. 21-37

Moonti, R. M. (2017). Hakikat Otonomi Daerah Dalam Sistem Ketatanegaraan Di Indonesia. Al-Ishlah: Jurnal Ilmiah Hukum, 19(2), 26-37.

Yarni, M. (2010). Fungsi legislasi DPRD dalam kerangka otonomi: studi kasus DPRD kota Jambi dan DPRD kabupaten Muaro Jambi. Jurnal Ilmiah Hukum LEGALITY.

Rahmat Qadri Nasrun, Husni Djalil, Efendi, 2019, Kedudukan Peraturan Daerah Yang Dibatalklan Oleh Keputuisan Menteri Dalam Negeri Setelah Putusan Mahkamah Konstitusi No. 137/PUU-XIII/2015, Syiaih Kuala Law Jurnal, Aceh ; Vol. 3, No. 1 April 2019. pp. 95-113

Ratna Solihah, Siti Witianti, 2016, Pelaksanaan Fungsi Legislasi Dewan Perwakilan Rakyat Pasca Pemilu 2014 : Permasalahan dan Usaha Mengatasinya, Jurnal Ilmu Pemerintahan “COSMOGOV” Vol. 2 No. 2, Oktober 2016. Program Studi Ilmu Fisip, Universitas Padjadjaran, Bandung. pp. 291-307. 
Lontoh, R. L. (2019). Problems of Border Regions in Ensuring Legal Certainty Invest in Indonesia. Substantive Justice International Journal of Law, 2(2), 118-136.

Soerjono Soekanto, Pengantar Penelitian Hukum, Cetakan III, UI Press, Jakarta, 2006.

Soetandjo Wignosubroto, dkk, 2005, Pasang Surut Otonomi Daerah: Sketsa Perjalanan 100 Tahun, Institute for Local Government.

Siti Zuhro R dan Eko Prasojo (Editor), Kisruh Peraturan Daerah: Mengurai Masalah dan Solusinya, Penerbit Ombak dan The Habibie Center, Yogyakarta, 2010.

Suharyo, 2015, Pembentukan Peraturan Daerah, dan Penerapan Sanksi Pidana Serta Problematikanya, Jurnal Rechtsvinding Media Pembinaan Hukum Nasional, Volume 4 No. 03 - Desember 2015. pp. 431-447

Suprin Na'a, 2016, Ke Arah Parlemen Lokal yang Berdaya, nusantaraku.org, Diakses Sabtu 23 Februari 2019

Wawan Sobari, dkk, 2004, Inovasi Sebagai Referensi: Tiga Tahun Otonomi Daerah dan Otonomi Award, Nailil Printika, Yogyakarta. 